\title{
Modernity, McDonaldisation and Family Values in Nigeria
}

\author{
A.O. Olutayo \& O. Akanle \\ University of Ibadan, Nigeria
}

DOI: $10.36108 / \mathrm{NJSA} / 7002 / 50(0140)$

Vol. 5 Issue 1, 2007

\begin{abstract}
Societies change as they come in contact with external influences and social organizations and relations become more complex. The nature of change may be dramatic or gradual and, in either case, change affects the norms, values, beliefs, attitudes, socialization process, and the general ethics that distinguish the group from every other, especially in this age of globalization. Since change can either be positive or negative and may have practical implications for survival of the society in question, it is imperative to interrogate observable transmogrifications being experienced. This paper examines the emerging culture of consumption in Nigeria within the purview of fast food as an element of modernity, which significantly drives change in the country and its implications for indigenous values and national development.
\end{abstract}

\section{Introduction}

Values are of central importance in every human society since they are the standards through which the essential and cherished are measured. A nation (society) without a clear value system is bound to be bedeviled with confusion and ultimately defocused because values are the nexus that connect the past with the present and guide the future. The place of values in societies are thus fundamentally strategic. Values determine modal behaviours in the society.' Thus, if there is no clear value system (or there is no value consensus) or the values are precipitately changing without conscious intervention the consequences might be dire.

Fundamentally, values are enmeshed in the family as the basic institution and primary agent of socialization. The family must therefore not fail in its socialization role because it is bound to be more efficacious than other socialization agencies due to the socio-psychological, economic, and even political sentiments that members enjoy in the family, which are often not replicated in other institutions. For example, the principle of sanction and reinforcement are first inculcated in the family and are bound to determine the way people perceive this process in other institutions. People who are not properly socialized or have not internalized $I$ correct' values may experience conflict and behavioural malformation when in contact with extra-familial institutions at later stages.

Societal survival is, therefore, to a large extent dependent on the performance of the family as a socialization agent. Unfortunately, however, there are issues in Nigeria that suggest a weakening in the family as an institution. The extended family system is fast becoming a myth as residential 
patterns are changing while frequency of visits and level of commitment are dwindling. Communities that used to be responsible for the individual upbringing - sometimes even by educating formally and informally - are no longer responsible.

Societies are more individual-focused today, as the nuclear family structure, and even single-parenting, is becoming 'popular when the dynamics guiding the composition and organization are not well comprehended. Socialization through kinship networks used to be community-based as values firmly reside in all and every elderly person, whether biologically related or not, was responsible for the values inculcated in the young ones. The conceptions of fatherhood and motherhood transcended biology. Respect for elders, for example, did not mean respect for those who share the same blood but whoever was older than the person involved.

Once the focus has shifted from the extended family relationship and community based socialization process, the consequences are values in a constant state of flux. It is against this backdrop that successive Federal Governments of Nigeria attempted and continues to attempt citizens' orientation and re-orientation as being fundamental to the attainment of desired development. This is done by inculcating the experience of the past in the present and the expectations of a befitting future. Examples of these attempts are: Mass Mobilization for Social and Economic Recovery (MAMSER) by the then military President, General Ibrahim Badamosi Babangida, The National Orientation Agency (NOA) and National Economic Empowerment and Development Strategy (NEEDS) (FGN, 2004). Whether the governments recognize(d) the mechanisms engendering the weakening of the value systems and if the right strategies are being adopted to achieve needed orientation are posers. Nonetheless, one of such ways through which Nigerian family ethics is being eroded is through food.

External influences on the indigenous value system in the country are profound. Nigerians are very receptive to foreign influences as observable in the preponderance of' modem' fast food restaurants. Even when they serve foreign cuisines mainly, the acceptance is astounding. The significance traditionally attached to food in Nigeria is remarkable as foods have sociocultural and even religious peculiarities to groups in the country. New yam, Iyan (pounded yam), Akpulfufu (pounded cassava) and Fura da Nunu (millet balls and cow milk) just to mention few, have sociocultural and environmental experiences' of groups embedded in them. The notions of "Tell me what you eat and I'll tell you who you are" and "you are what you eat" (Messer, 1984) are of importance in this situation. The search for, preparation, and the context of consumption of food are value laden and are often used ritually to mark social status, intervals in time, and culturally important environmental resources (Messer, 1984; Ohmagari, 2004; Pratt and Pratt, 1996).

Therefore, in the absence of sufficient and new literature on the interface 
of family ethics and modernity especially as it relates to the preponderance of fast food in Nigeria, this paper is inevitable. This paper attempts the analysis and generates issues that further researches could engage in. It must, however, be stated that while references shall be made to traditional/primordial and modern artifacts in Nigeria, it is not to suggest polarities (Gusfield, 1967; Nehring, 2006) as the two may co-exist in one form or another even though one may be dominant.

\section{Modernity, McDonaldization and Nigerian Family Values: Operationalisation and Theoretical Discourse}

Modernity connotes the type or model of society that arose in the West during the Enlightenment (Onyeonoru, 2005:23). It is initiated 'by changes in either technology or value .... '(Marshall, 1998:428) and according to Badru, (2004)' appears no longer as a quality with physical and spatial attributes, but as a "value in itself" a comparative category that can be identified, by its conformity with the western model'. For Giddens, 'modernity is inherently globalizing - this is evident in some of the most basic characteristics of modern institutions, including particularly their embeddedness and reflectivity' (Giddens, 2003). Summarizing its peculiarities, modernity, to Ritzer, is to be 'rational', 'calculable' and 'predictable' (Ritzer and Goodman, 2003: 556-557).

Literature is replete with the conception of modernity and observable consensus is that to be 'modern' is to be 'western'. A society is considered 'modern' to the extent that there is a flagrant display of 'western' artifacts in its sociocultural, economic and political system. It is against this background that Ritzer exemplifies modernity with the ascendancy and process of operating fast food outlets - McDonaldization - in the American society. In other words, Ritzer hinges his McDonaldization thesis on Weber's rationality. While Weber used bureaucracy as his exemplar of modernity, the process of operating and consuming fast food are the best ways of exemplifying modernity for Ritzer. He sees rationalization as 'coming to contain the entire life (and more)' (Ritzer, 1996). American society today experiences rationality in all its institutions from food, media, education, leisure, health care, and summarily, 'to birth and before death and beyond' (Ritzer, 1996). Definitely, the McDonaldization process includes the family as Ritzer refers to 'other sectors of the social world' (Ritzer and Goodman, 2003; Ritzer, 1996).

Modernity is, therefore, 'rationality', 'predictability', 'calculability', and 'efficiency' in the process of production, consumption, relationship and general patterns of doing things. In' modernized' societies, human actions are expected to conform with rationality and predictability especially as activities are dehumanized. As it is in the process of making fast food, indivi<l'illlls are expected to fit unsentimentally into their places on the social web. Fastness is expected as efficiency is non-negotiable and the process predictable. This has given preponderance to such phenomena as: Mcjobs, McUniversities, FastMoney and even McFamilies as family life is becoming calculable and 
McDonaldization becomes appreciable in the face of high rates of divorce, single parenting, civil partnerships and general lack of commitment even within marriage. The notion of 'Love is blind' no longer holds sway as individuals now evaluate what they stand to gain in any relationship.

These negative consequences of McDonaldization are what Ritzer terms 'irrationality of rationality'. According to him,' such a formal rational system brings with it various irrationalities, most notably the demystification and dehumanization of the dining experience' (Ritzer and Goodman, 2003:553). Although Kellner, (1999) argues that McDonald's, through its advertising campaigns, promotional stunts and outlets creates family togetherness, this is however superficial, formalized and conditioned. These restaurants systematically regulate consumers' behaviours to be fast, transient and hyper real creating nothing close to the real context of a family dining experience especially as Close Circuit Televisions (CCTVs) are strategically located to monitor behaviours of both staff and customers.

Role allocations are less emphasized and the traditional division of labour within households and associated benefits of socialization are consequently traded-off for rationality, predictability, efficiency and fastness as necessary concomitants of modernity. In sum, McDonaldization is an interrogation of contemporary social life to explain the changing nature of societies. As such, Ritzer believes it is at the moment difficult to stem the spread of rationalization and, spatially, we are witnessing the aggressive spread of rationality to other parts of the world with the United States as the core (Ritzer, 1996).

In an attempt to modernize, Euro-American societies are serving as benchmarks through which 'modernizing' societies measure 'progress' as determined by their level of conformity to 'standards'. Nigerian institutions, at least implicitly, are receptive to influences from the 'west' in the new world order. Indigenous values are continuously being harassed and almost subsumed under the impact of 'western' ideals. Indigenous values, attitudes, customs, norms and behaviours are gradually giving way for those which are modem. As the tide of rationality continues, structural changes are to be expected and; if possible, prepared for in the country. Utilizing Ritzer's McDonaldization thesis, it is noticeable that Nigerians are imbibing new values of modernity. At the extreme, it is then expected that this modem rationality, as displayed in the proliferation of fast food outlets, is most likely to have as much effect on the Nigerian social structure as it was and is the case in the western societies that are being replicated in Nigeria.

Family and value system, supposedly, are intricately intertwined but are to be disaggregated in this paper for analytical exigency. There is no generally acceptable definition of the family due to the high level of variations that exist in its structures and functions. To Ekong (2003), the family may be seen' as a kinship group linked by blood and marriage and occupying a common household'. As a social group, Ekong (2003) further sees the family as 'interacting and influencing the behaviours of each other 
in a more intimate manner than with others who do not belong'. For Otite and Ogionwo (2006), like Ekong (1984), family is a 'bio-social group' while for Marshall (1998) it 'is an ultimate domestic group made of people related to one another by bonds of blood, sexual mating, or legal ties'. From the foregoing, the family can be seen as a group of people sharing blood relationships (consanguine family) or non-blood relationship (conjugal). While there may be controversy about the universality of the family as a social institution, there is some level of agreement and that is the fact that it is the most basic and fundamental of all social institutions (Ekong 2003; Otite and Ogioriwo, 2006; Haralambos and Holborn, 2004; Badru, 2004; Haglund, 1982 and Marshall, 1996).

Marriage, while being a necessary precondition for family formation, is relative as a family can still be established without it in some societies and instances (Otite and Ogionwo, 2006). There are however rules governing marriage and family and these are essential. Sexual relations are governed by incest and taboos and these have necessitated exogamy and endogamy. Families can be nuclear or extended. A Nuclear family is that which consists of the father, mother and their children. According to Ekong (2003), 'priority is given to marital bond rather than blood in this kind of family... ' The Extended family involves generations of people bound by blood relations. An individual is born into a family and this is the family of orientation while the one established by an individual with his/her spouse is, the family of procreation.

The family as a social institution performs specific functions. For Ekong (2003) these functions can be divided into two broad types; functions to the individual and those to the society. For Otite and Ogionwo (2006) these functions are the same and not necessarily divided. The same functions are also explicated in the work of Badru (2004). Thus, functions of the family include: procreation, socialization, conferment of identity, regulation of sexual activities of members, emotional support, economic empowerment and, as succinctly put by Otite and Ogionwo (2006: 60), 'it is a means of providing the social capital needed for the society and its organizations'. These become values as they are inculcated into the children who, in turn, are expected to reproduce such values in their children.

Values are the expected mode of behaviour in society. They are principles and ideals that govern or regulate the behaviours of people in societies. Values are created which individuals must aspire to within the normative framework and they provide the criteria and conceptions by which relative worth, merit, beauty or morality of people, objects and events are evaluated (Hughes, et al., 1999). Although what constitutes values vary across board, every society has values embedded in it in one form or another. While in some societies it is hard work that is valued, in another it may be being sexy while it may be adherence to religious dictates in some others. The crux of the argument is that once values are created people are expected to acquire such values and the norms guiding this process are given to make human 
relationships predictable for societal survival. Deviations from values are sanctioned while conformity is rewarded to reinforce that particular expected behaviour. The target of values - even though they are usually abstract - is for group identity, maintenance, organization, predictability and perpetuity.

Family values suggest the fundamental and unrivaled role of the family as the main institution that embodies and must incorporate vital values into the individual members of the society. It further suggests the need for values, as locomotives of national development (Gichure, 2008). Family values in Nigeria connote the places of indigenous philosophies and family dynamics in national identity formation and maintenance, national development and capacity building. Nigerian family values therefore place unique emphasis on some important indigenous ways of life contingent upon languages, customs, ethics, civilizations and national experiences that inform necessary actions in $I$ modem' times. Although ethical values may not always be shared precisely the same way, the need to emphasize the family and society's collective interests can not be over emphasized (Shinn, 2006). While China has been elaborately acknowledged as the emerging super power, its socioeconomic and political ascendancy are based .on its incorporation of Confucian principles of family and collective interests (Shinn, 2006).

These principles are incidentally not strange to the Nigerian society as they correspond to the original structure of African societies based on the preeminence of the extended family and its mutuality of care, concern, and support (Rafael, 2007). In the face of emerging social transformations and continuous erosion of indigenous moral values, substitution of altruism for self interests and an attendant high level of generalized corruption (Gichure, 2008) therefore, the need to embrace a Nigerian value and ethical world view thus exists and the family must take the lead as no other institution has the capacity in real terms. This framework recognizes the "local" within the "global", that is, "thinking locally and acting globally" (Guchere, 2008). This is the respect for local ethos and active participation in global ethical dialogue.

\section{The Fast Food Landscape in Nigeria}

Fast food is any food prepared out of the consumers' home and is ready for consumption at the point of purchase. Moreover, fast food may be 'eat in' or 'take-away'. By implication, traditional foods that are sold in sheds/kiosks/stalls (Bukas) and those on sale through hawking should be considered as fast food since they are ready for consumption at any point in time. Bukas deal in cuisines largely peculiar to the sociocultural environment in which they are found. Some of their delicacies include; Akara (bean cake), Rice and Beans with stew, eba (meal made from cassava flour) with soup, boli (roasted plantain), Akpulfufu (pounded cassava) with soup, Iyan (pounded yam) with soup and Fura da Nunu (millet Balls and cow milk) amongst others (Pearce, et al., 1988; Giami, 2004).

The patterns of service of Bukas are identical to those of 'modem' fast 
food outlets as they serve breakfast, lunch and supper. According to Pearce, et al., (1988), Bukas have a wide variety of foods that one may find up to 335 varieties prepared for the public and they vary according to the time of the day and season of the year. In spite of the fact that they meet the socioeconomic and cultural needs of people however, Bukas have been found to suffer constant harassment from policy makers and the authorities and the it services are often associated with being too cheap, poverty, unhygienic conditions, illiteracy and, consequently, calls for government interference (Kennedy, 2003; Opare-Obisaw, 1998; Pearce, et al., 1988; Iyun 1992; Ruel, et al., 1999; Igboanusi, 2002).

The sentiments against Bukas are, by and large, traceable to the effects of structural and institutionalisation of modernity in Nigerian society. What is being witnessed on the Nigerian fast food scene is 'implicit structural homogenization' (Ram, 2004:26). Nigerians take fast food to be only as it is obtainable in the 'west' and relate as such while identical patterns that are indigenous are subsumed. While Ram (2004) finds that McDonaldization engenders the renaissance of Israeli's national food habits, falafel, it is yet to be seen if the same can be said of Nigerians' as more seem to be joining the tide sweeping towards 'modern' one.

Fast food restaurants operate through their outlets and they are formalised means of consumption - with their implications - and are strategically located to suit their purpose(s) and that of their target consumers. Although they have their origins outside Nigeria and are often symbolized by McDonald's restaurants in the literature, they have unarguably assumed the status of' the 'visible companion' in Nigerian cities.

The origin of the fast food industry in the country is traceable to the late 1970s and early 1980s with very few like king's way snacks, leventis snacks, De facto and Kas chicken (NigerianBusinessInfo.com, 2000-2001). Today, however, the country is witnessing a preponderance of fast food outlets and 'currently Nigeria can boast of over 70 different brand names .... and (i) is difficult to escape noticing the colourful edifices and billboards of these fast food outlets' (NigerianBusinessInfo.com, 2000-2001).

The Growth Rate (GR) of restaurants and hotels, has constantly been on the increase from 4.50 in 2001 to 13.00 in 2005 (NBS, 2006) implying an almost tripling effect in the GR while the number of restaurants is to double in 5 years. The viability of this industry is never in doubt as new brands enter the market on a daily basis just as the old ones open new outlets in strategic locations. This viability has led to the incursions of international brands. They include, Steers, Chicken Lickens and St. Elmos, all well established South African brands with $40-50$ percent of international brands while the United States has about 5 percent (Eke, 2006).

The biggest of these chains of fast food restaurants is Mr. Bigg's with outlets both in and out of the country. Other popular names include; Sweet sensation, Tantalizers, Tasty Fried Chicken, Big Treat, Kas Kitchen, Friends, Chiquita, Tetrazzini, Domino Dina and Trend's; amongst others 
(NigerianBusinessInfo.Com, 2000-2001). Of fundamental importance is the unprecedented rate of the spread of some of these restaurants and the high level of patronage they enjoy to the extent that it has become one of the most vibrant industries in the Nigerian economy. Their effect on the consumption pattern of Nigerians and, by implication, the family, is bound to be farreaching. This is because the benefits usually derivable from the traditional, collective ways of eating in family settings are being traded off. It has been empirically confirmed that most of the consumers of fast foods are the youths and they eat independent of their families in most cases (Olutayo and Akanle, forthcoming). Inter-generational linkages in the contexts of eating are compromised as the youths usually eat at fast food restaurants independent of the elders who do not appreciate such consumption patterns. This is due to health implications and preference for that which is prepared and eaten at home (Olutayo and Akanle, forthcoming).

This new means of consumption is largely American and has only been imported into Nigeria where it is having a profound effect on consumption (Ritzer and Goodman, 2003). Hence, the technologies that are used in the production of these products are mainly imported therefore creating further dependence on the center (Kambhampati, 2004:74; Olutayo and Bankole, 2002).

\section{Modernity, Collective Consumption Pattern and Nigerian Family Values: The National Scenario}

Nigeria is no doubt a rapidly changing society. The kind of change being experienced in the country is unprecedented. The scenario can be captured more vividly in statements such as: 'It can no longer be business as usual' . Any discourse on family values in Nigeria must acknowledge the point that it varies widely given the multi-ethnic nature of the country (FGN, 2004; Ekong, 2003; Otite and Ogionwo, 2006: 266-267). It is then expected that Nigeria is bound to have values that may be diverse according to different languages and ethnic orientations. However, since different ethnic groups have always closely interacted in Nigeria based on trade, migration, routes, religion, diplomacy and even war (Dioka, 1997; Oduwobi and lwuagwu, 1997; Ekeh, 1989), it is then expected that these culture contacts must have engendered cultural diffusion and acculturation such that identical values may be obtainable in the country.

As noted above, Ekeh (1989) equally observed that 'Nigeria, along with other African countries, is experiencing the emergence of a nation-wide cultural norms values and institutions that qualify to be called Nigerian nation-wide culture'. To distinguish this 'nation-wide culture' from 'ethnically distinct cultures,' Ekeh (1989) adopted the 'primordial and civil culture' framework. Since Nigeria is the unit of analysis, it is then possible to consider 'Nigerian family values' even though this paper recognizes some variations in these values.

Since the family is the embodiment of values, it is the first institution to 
inculcate these values in the new members in the society. For instance, Nigerians are expected to respect elders even though modes of expression vary. While amongst the Yorubas of the southwest it is by prostrating and kneeling, amongst the Hausas of the north it is by squatting and raising the knuckles while amongst the Igbos of the southeast it is sometimes through handshakes. In traditional Nigeria, values of hard work, honesty, chastity, faithfulness, respect for authority, accountability, patriotism, punctuality, dignity, care for others and virtues were strongly entrenched in the primordial institutions and were covertly policed through the family since, expectedly, 'charity begins at home' and members must always 'remember the children of whom they are.'

Whoever contravened these values was sanctioned without partiality. For instance, in the Old Oyo empire with its traditional checks and balances, if the king (Alafin) was found wanting for gross misconduct he was expected to commit suicide - oba sigba (Agbogu, 1997) while the Are Onakakanfo (The Yoruba generalissimo or Head of the army) was expected to commit suicide if defeated in battle. Nigerians were properly socialized into values, norms and customs in the pre-colonial era beginning from the family and this ensured relative order in the society.

Apart from the internal structures that sustained the societal ethos, people regulated their external relations. Foreign incursions were dealt with decisively to protect the society from disruptive influences. When these regulations become problematic, force may even be adopted to save the group from influences that may be detrimental (Dioka, 1997).

Hence, within families, roles are allocated and everybody is expected to perform his or her roles for the benefit of all. The husband/ father is expected to provide for the needs of the wife, children and others while the wife/mother is expected to meet the needs of the husband, children and necessary others. The children are also to be responsible for their own roles. As social relations become more complex, these roles must not be in conflict to prevent strain but if it happens, they must be resolved for the ultimate good. Irrespective of the type of family, roles are allocated and expectations upheld. These roles and kinship relations have implications for the survival of value and the society as they serve 'as vital linkages in binding the individual family groups into the larger community' (Thornton and Fricke, 1987).

It is this vital linkage that has been responsible for extended relationships. Once this linkage is severed, a dislocation is to be expected between the individual and the larger community. A shift from being 'my brother's keeper' to extreme individuality is thus inevitable. By implication, a move from collectivity to individuality is the ultimate result of uncensored relationships in a society that was hitherto closely knitted. Nigerians are usually loyal to the family because of the functions it performs. People inherit through the family, bear the family names, and even sometimes marry through the family. Relatively, the umbilical cord connecting the individual 
to the family is strong. Although the Nigerian society is in a state of continuous change due to dynamics that may be internal, the current wave of change in the country displays a toga of extreme externalities.

According to Vaughan (2005) 'the global era ushered in a notable crisis of the postcolonial Nigerian state'. For instance, privatization and commercialization, unadapted democracy, new migration and cultural patterns (Vaughan, 2005; Olutayo and Omobowale, '2005) are all gaining momentum in the country and the effects are profound on indigenous family values as they constantly interact. Although the family still performs some of its traditional roles (Afonja and Pearce, 1984; Ekong, 1984), the traditional values and its process of inculcation and perpetuation is no doubt being compromised. While more Nigerians are still rural dwellers - above sixtypercent $(60 \%)$ - Ekong (2003), the rate of urbanization and urbanism is increasing at an alarming rate (Gbadegesin, 1994, Kennedy, 2003, Ruel, 1999, Pearce, et al, 1988) and the effects of modernization are more profound at the urban centers due to their constant contact with foreign cultures.

It is then predictable that the influence of modernization is not likely to rescind soon. As Nigerians imbibe modernity, they become 'rational' 'calculable' and' predictable' in the ways of modern ideals. In the modern era, home, family, work/industry, education and even religion become separated. Families spend less time together and more time out of the home. The situation is best appreciated in the 'mega cities' of Nigeria where couples and their off springs may depart at dawn only to reunite at dusk, weeks or even months in some instances.

The culture of eating together at home and the filial bond it creates is steadily becoming unpopular. In a society that is modernizing and imbibing fastness that is ever associated with it - 'time is money' - the emergence of fast food restaurants is only timely. To make these restaurants' a home away from home', Nigerian cuisines are being introduced into the menu charts (NigerianBusinessInfo.com, 2000-2001). The poser, socially though, then is: is it the food or the intangible filiations and sentiments associated with the habit? While, socially, the problem is not the fast food, the process that necessitated it and the challenges it has created are.

Eating together in a typical traditional Nigerian family serves a lot of functions. These functions include social control and efficacious process of socialization. 'The context of eating together enables the parents to understudy the children and even the spouse for attitudinal/behavioural change and appropriate correction is given, if necessary. Withdrawal of food from a child may serve as a corrective measure for anti-social behaviour while an additional meal from parents may serve as reinforcement of valued behaviour. In essence, the context of eating together at home is germane in so many respects especially as it creates a propensity for togetherness. Schouten and McAlexander (1995) similarly observed that' people identify with certain objects or communication activities and through those objects or activities identify with other people.' 
In other words, when people cook and eat together .the bonds of filiations that sustain the family and the nation are reconfirmed and strengthened. Eating together in households and family contexts is strategically archetypical of African communal value and has given Africa its unique identity. This must not be compromised. Thus, eating together in normal and ideal family contexts is essential as it resonates necessary communal values, communality and uniformity that are necessary for nation building.

Though it can be argued that eating in fast food restaurants have some positive impacts on shedding some traditional socialization elements that may result in subjects' (especially children) victimization in an attempt to mold character. For example, withdrawal of food even when a child is hungry, beating, threatening, verbal abuse (name calling), hard labour and other forms of violence (UNICEF, 2005) can not be easily perpetrated in fast food restaurants as lots of people from various cultural and socioeconomic backgrounds eat in the $I$ open floor' regardless of familial idiosyncrasies. They 'expect' all present to be 'civilized.'

Suffice it however to maintain that physical proximity and exclusiveness in food consumption, and food sharing thereof, are closely linked to notions of kinship and central to social relations (Notemans, 2004) as nonverbal communications are often adopted as a vehicle of socialization in the traditional context of food consumption. A child may be instructed through eye-contact to which obedience is expected and this is well ingrained in the social structure of societies, like that of the Yoruba, that a child sensitive to eye contact may be referred to as Omo oju (a child that obeys eye contact instructions). Even when families eat together in a fast food restaurant, it is always for a comparatively short duration as people are not even expected to stay longer than necessary. Besides, fast food restaurants are not contexts for sensitive character molding.

The strategic nature and efficacy of strong inter-generational kinship relations have been well documented in literature (Notemans, 2004; Whyte, Alber and Geissler, 2004; Alber, 2004; Van Der Geest, 2004; Ingstad, 2004; Whyte and Whyte, 2004; Van Ufford, 2004 and Kellner, 1999) and the consensus is that, though the older generations and the younger ones share different experiences, their existence overlaps through kinship and they must be abridged for the past, present and future to interconnect for societal survival.

Achieving this interconnectedness thus poses a challenge as the younger generation (the youths) eat alone independent of the older generations (Olayiwola, Soyibo and Atinmo, 2004:10) paying little or no attention to the norms and values (social capital) that can be inculcated in the context of eating. Actions such as 'who picks what and when' in traditional societies teach role allocation and respect for elders and constituted authorities which are central to social order. Nature and context of food consumption cement social relations and experiences as stories are told which may symbolically teach "bravery", 'discipline' or community history relevant to the future of 
the society in question. The above position is succinctly captured in Ridington and Ridington (2004) in which they maintained that stories are often strategic in the socialization process and identity maintenance and according to them: "Those stories I remember, that's what I live by now."

Once families no longer spend sufficient time together due to modernity and they spend less time socializing the children, they (the children) become vulnerable to modern values that they may easily internalize especially when those values are resonated in their peer groups. Likewise, Thorton and Fricke (1987) opined that [under circumstances where parents are less able to observe, supervise and, control their children, it becomes easier for children to be influenced by others and to redefine their values and behaviour in a nonfamilial context.... .'

It is then less surprising that there are so many incursions of foreign values, which are often antithetical to local ideals. According to Ekong (2003), there have been changes in Nigerian families to the extent that children are no longer well prepared for marriage, there is less emphasis on virginity as a desired virtue and extreme individuality in marriage and family arrangement. The line between valuable and undesirable has become blurred.

It suffices to note that much of the social ills that bedevil the country today are traceable to the changes in the relationship within the family institution as noticeable in eating outdoors. An improperly socialized child is a potential rapist, thief, commercial sex worker (CSW), cheat, fraud among others too numerous to mention. The level of sexual permissiveness for instance, is so grave that Sedgth, et al. (2006) discovered that in their community based study in Nigeria' forty-three percent of women who sought an abortion did so because they were not married, were too young or were still in school.

As Nigeria attempts to develop, there is a need to constantly pose the question: what are the effects of these efforts on the local institutions and what are the effects of the local institutions on the development efforts? Imported policies and artifacts of modernization are values laden and they represent a particular level of cultural evolution in the societies of origin. For example, the large-scale introduction of the steam engine in Europe and America brought about what has come to be known as the 'Industrial Revolution' (Onyeonoru, 2005:2). Since the steam engine altered the mode and system of production, it led to an alternation in relation to production and the emergence of new social vices. A fundamental case was a shift of productive activities from the family to the factories as contexts of production.

In related fashion, the introduction of satellite television and mass media in general is altering and making the conception of values fluid in societies (Gidden, 2003; Thompson, 2003; Smith, 2003; Norris, 2003). Once McDonaldization is a necessary concomitant of industrialization and Nigeria is industrializing, fast food then can always be expected to proliferate. Meanwhile, fast food has been associated with numerous health problems 
ranging from obesity to cancer to the extent that materials (for instance books) dedicated to related consumption patterns are selling in their millions (Atkins, 2003a; Atkins, 2003b).

While the enormity of these problems has led to a decline in the sale of fast food in Europe and America, the reverse is still the case in Nigeria (Olutayo and Akanle, forthcoming). Values like; avarice, individuality, insensitive leadership and associated factors have found pronouncement in Nigeria. The implications of these are evident against the backdrop of an insatiable appetite for imported and luxurious goods as well as cyber crime (yahoo yahoo in local parlance) among the youths (Akanle, 2007). The values being imported are already problematic in their societies of origin and are expressly obvious as Britain now ranks among the highest for violence, drunkenness, promiscuity and general anti-social behaviour (Saturday Punch, February 17, 2007). These problems are so challenging that they have been institutionalized as the government has instituted 'the Anti-Social Behaviour Order (ASBO) which is imposed on offenders that are underage.

It is the position of this paper, ultimately that no matter what Nigeria wishes to achieve, if it compromises the fundamental values (embodied basically in the family) that give Nigerians their identities, meaning and perpetuation, it is not development since it is bound not to be sustainable in the long run.

\section{Conclusion}

This paper has examined the challenges faced by Nigeria in relation to its family values. While fast food is used for the analysis to better explore the dynamics of development in the country, it is only to give a vivid account of the changes being experienced and their implications for the survival of strategic value systems necessary for sustainable development.

People find attachment to a value system that is modem and as modernity becomes acceptable, especially when there is no concerted effort to control its influence, the consequences may endure. Modernity does not necessarily translate to development that is sustainable and it may be insightful to acknowledge the fact that local values have beneficial ingredients that are germane for development. These should be properly harnessed especially as development in all ramifications must be localized.

Fast food emerged as an adjustment mechanism with an understanding of a way of life in the countries of origin, thus, since Nigeria is a peculiar physical and sociocultural society; it should pay attention to its uniqueness in utilizing emerging artifacts like fast foods. As fast food is embraced in Nigeria, it is the best time to begin to take stock of its impact on the social system. This is the least Nigerian scholars can do as the intellectual brain box and vanguard of the nation. Development in Nigeria must be total and all inclusive. The indicators being used as at now are faulty and fundamentally unacceptable. It is therefore not surprising that the celebration of developmental achievement in some quarters of the country is not reflective 
of reality. Therefore, policies of government should be ones that, take care of all. National orientation and/or re-orientation efforts must be "sold" to the people wielding sentiments about the family if they are to be efficacious. In other words, efforts of government must be well situated within the family because it is within the family that the society is embedded: its past, present and certainly the future.

\section{References:}

Afonja, S. and Pearce, T.O. 1984. Social Changes in Nigeria: A Theoretical Exploration of the path and the goal in S. Afonja, and T.O. Pearce (eds.) Social Change in Nigeria. England: Longrnan Group.

Agbogu, AE. 1997. African Traditional Political System in AE. Agbogu, (ed.) Aspects of social science. A handbook for social science, Nigeria: Readon Publishers Ltd.

Akanle, O. 2007. Immigration Cultism and the Nigerian Migrants: Tidal dynamism in the Age of Globalization. Conference paper delivered at the joint international conference on Globalization: Migrants, Citizenship and Identity. Organized by Kennesaw State University U.S.A and Department of History, University of Ibadan, 6th-9th November, 2007. The paper has been accepted for publication in Globalization and Trimsnaiional Migrations: African and Africa in the contemporary Global System. UK: Cambridge Scholars Publishing http://www.c-s-p.org/

Alber, E. 2004. Grandparents as Foster Parents: transformations in foster relations between grandparents and grandchild in North Benin. Africa 74(1): pp. 28-46.

Atkins, R.C. 2003a. Dr. Atkins for life: The Next Diet Revolution. London: Vermillion.

2003b. Atkins for Life: The Net Diet Level. New York: Macmillan. Badru, F.A 2004. Urbanization, family and social changes in Nigeria: 1950-1999 in M.O.A. Adejugbe, (ed.) Industrialization, urbanization and developmentation Nigeria: 1950-1999. Nigeria Concept publication Ltd.

Dioka, L.C. 1997. Inter-Group Relations Among Nigeria Communities in A Oshuntokun, and A Olukoju (eds.) Nigerian Peoples and Cultures. Nigeria: Davidson press.

Eke, C. 2006. The Fast Food Business in Nigeria. A Report Prepared for The U.S. Commercial Service. ID:\#137173.

http://commercecan.ic.gc.ca/scdtjbizmap/interface2.nsf/velodownload/IS A554 3/ \&file/x7603146.Doc. Accessed 08/062007.

Ekeh, P.P. 1989. The Scope of Culture in Nigeria in P.P. Ekeh., and G. Asiwaju, (eds.) Nigeria: Since Independence: the first 25 years. Vol. Viii.

Ekong, E.E. 2003. Rural Sociology: An Introduction and Analysis of Rural Nigeria. Nigeria: Dove Educational publishers.

Ekong, S.C. 1984. Community and Change in Nigerian family Patterns in S. Afonja, and T.O. Pearce, eds. Social Change in Nigeria. England: Longman Group. 
Federal Government of Nigeria (FGN) 2004. Nigeria: National Economic Empowerment and Development Strategy. (NEEDS). Abuja: NEEDS Secretariat.

Gbadegesin, A.S. 1994. Agricultural Practices in M.O. Filani, F.O. Akintola, and C.O. Ikopuru (eds.) Ibadan Region. Rexcharles and Connel publications.

Giami, S.Y. Influence of Cowpea (Vigna Unguiculata L Walp) variety on Protein quality and sensory proeprties of akara, a popular West African Cowpea-based food. Journal of the Science of Food and Agriculture. 85(2). Pp. 261-264.

Gichure, C.W. 2008. Ethics for Africa. today: An Introduction for Business Ethics. Paulines Institutes Publisher.

Giddens, A. 2003. The Globalization of Modernity in D. Held, and A.

McGrew, (eds). The Global Transformations Reader: An Introduction to the globalization debate. UK: polity press.

Gusfield, J.R. 1967. Tradition and Modernity: Misplaced Polarities in the Study of Social Change. American Journal of Sociology. 72 (4): p.351.

Haglund, E. 1982. Moral Education in a Third World Society: Southeastern 'Nigeria. Curriculum Inquiry. 12(4). P.363.

Haralambos, M and Holborn, M. 2004. Sodology: Themes and Perspectives. London: Harper Collins Publishers Ltd.

Hughes, M., Kroehler, C.J. and Zanden, J.N.V. 1999. Sociology: The Core. McGraw-Hill.

Igboanusi, H. 2002. A Dictionary of Nigerian English Usage. Nigeria: Enicrownfit Publishers.

Ingstad, B. 2004. The Value of grandchildren: changing relations between generations in Botswana, Africa. 74(1). Pp. 62-75.

Iyun, B.F. 1992. Women's Status and Childhood Mortality in Two Contrasting areas in South-Western Nigeria. GeoJournal. 26(1). Pp:43-52.

Kambharnpati, U.S. 2004. Development and the Developing World. U.K. Polity Press.

Kellner, D. 1999. Theorizing/Resisting McDonaldization: A Multiperspective Approach.http://www.gseris/ucla.edu/faculty/kellner/kellner.htrnl.

Accessed on 09/03/07.

Kennedy, G. 2003. Food Security in the Context of Urban Sub-Saharan Africa. Food Africa, Internet Forum. Http://foodafrica.nrLorg. Accessed on 07/03/07.

Marshall, G. 1998. Oxford Dictionary of Sociology. UK: Oxford University Press.

Messer, E. 1984. Anthropological Perspectives on Diet. Annual Review of Anthropology. 13 pp. 205-249.

Nehring, D. 2006. The Same, but Different: Reflections on Gender, Modernity and Social Change in Mexico. The Essex Graduate Journal of Sociology. Feb. (6). Pp. 52-67.

Nigerian Bureau d-statistics (NBS) 2006. The Nigerian Statistical Fact Sheets 
on Economic and Social Development, Nigeria: National Bureau of Statistics.

NigerianBusinesslnfo.Com.2000-2001. The Fast Track Nigerian Fast Food Industry.

Norris, P. 2003. Global Governance and Cosmopolitan Citizens in. D. Held, and A. McGrew, (Eds.) The Global Transformation Readers: An Introduction to the Globalization Debate. UK: Polity Press.

Notemans, C. 2004. Sharing Home, Food and Bed: Paths of Grand Motherhood in East Cameroun. Africa. 74(1):pp. 6-27.

Oduwobi, T. and Iwuagwu, O. 1997. Nigeria: An ethno-Historical Survey in A. Oshuntokun, and A. Olukoju (eds.). Nigerian Peoples and Cultures. Nigeria: Davidson Press.

Ohmagari, K. 2004. The Role of Traditional Food in Identity Development among the Western James Bay Cree. In T. Irimoto, and T. Yamada (eds.). Circumpolar Ethnicity, and Identity. Senri Ethnological Studies. No. 66. Pp. 127-138.

Olayiwola, K.; Soyibo, A. and Atinmo, T. 2004. Impact of globalization on food consumption health and nutrition in Nigeria, in UNISA (ed.). Globalization of Food Systems in Developing Countries: Impact on Food Security and Nutrition.

http://www.un.org/Depts/dhl/food/toc.4/pdf.Accessed24/April/2007.

Olutayo, A.O. and Akanle, O. Forthcoming. Fast Food in Ibadan Metropolis: An interrogation of an Emerging Consumption Pattern. Africa. A journal being published by the Edinburgh University, UK.

Olutayo, A.O. and Bankole, A.O. 2002. The Concept of Development in Historical Perspective: The Third World Experience in U.C. IsiugoAbanihe, A.N. Isamah, and J.O. Adesina (eds.) Currents and Perspectives in Sociology. Nigeria: Malthouse Press Ltd.

Olutayo, A.O. and Omobowale, A.O. 2005. Globalization, Democracy and the New Partnership for African Development (NEPAD). African Journal of the Psychological Study of Social Issues. 8(2).

Onyeonoru, I.P. 2005. Industrial Sociology: An African Perspective, Nigeria: Samland Publishers.

Opare-Obisaw, C.1998. Students' Patronage and Views on the operations and services of food vendors. Journal of Consumer Studies \& Home Economics. 22(3). Pp. 139-146.

Otite, O. and Ogionwo, W. 2006. An Introduction to Sociological Studies. Nigeria: Heinemann Educational Books.

Pearce, T.O.; Kujore, O.O.; Aghoh-Bankole, V.A. 1988. Generating an Income in the Urban Environment: The Experience of Street Food Vendors in IleHe, Nigeria. Africa: Journal of the International African Institute. 58(4). Pp. 385-400.

Pratt, C.A. and Pratt. C.B. 1996. Nutrition Advertisements in consumer Magazines: Health Implication for African Americans. Journal of Black 
Studies. 26(4). Pp. 504-523.

Rafael, C 2007. Information Ethics for and from Africa. Keynote address at the African Information Ethics Conference. Pretoria, South Africa. 5th-7th February.

Ram, U. 2004. Glocommodification: How the Global Consumes the Local McDonald's in Isreal Current Sociology. 52(1): pp. 11-31.

Ridington, J. and Ridington, R. 2004. Maintaining Dane-Zaa Identity: "those Stody I Remember, That'S What I live by Now", in Irimoto, T. and Yamanda, T. eds. Cicumpolar Ethnicity and Identity. Senri Ethnological Studies. No. 66. Pp. 161-174.

Ritzer, G. 1996. The McDonaldization Thesis: Is expansion inevitable? International Sociology. 11(3): pp. 291-308.

Ritzer, G. and Goodman, D.J. 2003. Sociological Theory. McGraw Hill.

Ruel, M.T., Haddad, L., and Garrett, J.L. 1999. Some Urban Facts of Life: Implications for Research and Policy. Food Consumption and Nutrition Division. (FCND). Discussion Paper. No. 64.

Saturday Punch, February 17, 2007. The UK of Your Dream.

Schouter, J.W. and McAlexander, J.H. 1995. Subculture of Consumption: An Ethnography of new Bikers. The Journal of Consumer Research. 22(1): pp. 43-61.

Sedgh, G., Bankole, A., Oye-Adeniran, B., Adewole, I.F., Sigh, S. and Hussain, R. 2006. Unwanted Pregnancy and Associated factors among Nigerian women. International Fairly Planning Perspectives. Pp. 175-184.

Shinn, D. 2006. The China factor in African Ethics. Policy Innooations. The Carnegie online.

Smith, A.D. 2003. Towards a Global Culture? D. Held, and A. McCrew, (eds.). The Global Transformations Readers: An Introduction to the Globalization Debate. UK. Polity Press.

Thompson, J.B. 2003. The Globalization of Community in D. Held A., McGrew (eds.). The Global Transformations Readers: An Introduction to the Globalization Debate. UK. Polity Press.

Thornton, A. and Fricke, T.E. 1987. Social Change and the Family: Comparative Perspectives from the West, China and South Asia. Sociological Forum. 2(4): pp. 764-799.

UNICEF, 2005. Speaking Out: UN Study on Violence against Children. February, No.14. http://www.unicef.org/voy /

Van Der Geest, S. 2004. Grandparents and grandchildren in Kwahu, Ghana: the performance of respect. Africa. 74(1): pp. 47-61.

Van Ufford, P.Q. 2004. Shared Lives: exploring practices of amity between grandmothers and grandchildren in Western Kenya. Africa. 74(1): pp. 95120.

Vanghan, 0.2005. The Crisis of the Nigerian State in the Global Era in O. Vanghan, M. Wright, and C. Small. (eds.) Globalization and marginalization Ibadan: Sefer Books Ltd.

White, M.A. and Whyte, S.R. 2004. Children's Children: time and relatedness 
62 The Nigerian Journal of Sociology and Anthropology Vol. 5

in European Uganda. Africa. 74(1): pp. 76-94.

White, S.R..; Alber, E. and Geissler, P.W. 2004. Lifetimes Intertwined: African Grandparents and Grandchildren. Africa. 74(1). Pp. 1-5. 